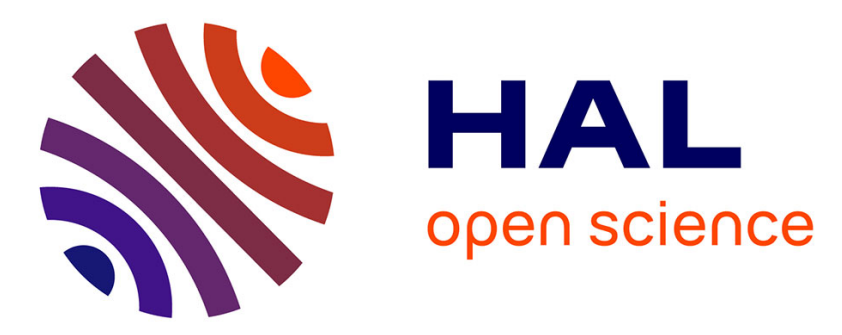

\title{
The Upper Rhine Graben (URG) revisited: Miocene transtension and transpression account for the observed first-order structures
}

Yair Rotstein, Marc Schaming

\section{- To cite this version:}

Yair Rotstein, Marc Schaming. The Upper Rhine Graben (URG) revisited: Miocene transtension and transpression account for the observed first-order structures. Tectonics, 2011, 30, pp.TC3007. 10.1029/2010TC002767 . hal-00722529

HAL Id: hal-00722529

https://hal.science/hal-00722529

Submitted on 16 Jun 2021

HAL is a multi-disciplinary open access archive for the deposit and dissemination of scientific research documents, whether they are published or not. The documents may come from teaching and research institutions in France or abroad, or from public or private research centers.
L'archive ouverte pluridisciplinaire HAL, est destinée au dépôt et à la diffusion de documents scientifiques de niveau recherche, publiés ou non, émanant des établissements d'enseignement et de recherche français ou étrangers, des laboratoires publics ou privés.

$$
\text { Copyright }
$$




\title{
The Upper Rhine Graben (URG) revisited: Miocene transtension and transpression account for the observed first-order structures
}

\author{
Y. Rotstein ${ }^{1,2}$ and M. Schaming ${ }^{1}$ \\ Received 23 July 2010; revised 7 March 2011; accepted 11 March 2011; published 16 June 2011.
}

[1] Although the Upper Rhine Graben (URG) has been studied extensively for years, the origin of some of its first-order structures is still under debate, particularly the relatively young uplift of the Vosges Mountains (VM) and Black Forest Mountains (BFM). Their uplift appears to be temporally related to the change of the URG into a continental transform, the rapid subsidence of its deep northern basin, and the onset of erosional and nondepositional phase south of the Northern Basin. Recent observations from newly released seismic reflection data, coupled with older geologic and seismic observations, are used to explain this correlation. We suggest that when the URG turned into a continental transform during the early Miocene, not only was its northern basin transtensionally subsiding as previously suggested, but the VM and BFM were transpressionally uplifted. Transpression became weaker with growing distance from the Alpine front, and north of Baden-Baden the transpression is expressed only by down-buckling of the sediments, forming a deep, elongated syncline. The largest uplifts and erosion associated with this event occurred along both boundaries of the southern URG. However, the center of the graben was also affected to some extent, causing widespread erosion of pre-early Miocene sediments and subsequent nondeposition. The arcuate Vosges and Black Forest fault systems, which formed the boundary faults of the URG during the Oligocene, became mechanically unfavorable during the Miocene transpressional regime. Instead, more linear normal faults took over as the dominant boundary faults, forming the western and eastern Rhine Fault systems and assuming a strike-slip component of motion.

Citation: Rotstein, Y., and M. Schaming (2011), The Upper Rhine Graben (URG) revisited: Miocene transtension and transpression account for the observed first-order structures, Tectonics, 30, TC3007, doi:10.1029/2010TC002767.

\section{Introduction}

[2] The Upper Rhine Graben (URG) (Figure 1) is a major structural element of the Central European Rift System [Ziegler, 1992, 1994]. The geology of the URG, which is situated in the heart of one of the world's most scientifically advanced regions, has been investigated for over a hundred years [e.g., Sittler, 1969; Illies, 1972, 1974; Teichmüller and Teichmüller, 1979; Pflug, 1982; Hüttner, 1991; Sissingh, 1998, 2003; Lutz and Cleintuar, 1999; Schumacher, 2002]. Nevertheless, key elements in its presently observed structure are not well accounted for, or are still under debate. Most notable of these is the basic rift structure, namely the occurrence of elevated shoulders on both sides of the southern and central parts of the rift, and to a lesser extent in its northern part. It is now commonly accepted that the Vosges Mountains (VM) and Black Forest

\footnotetext{
${ }^{1}$ Institut de Physique du Globe de Strasbourg, UMR 7516, Université de Strasbourg/EOST, CNRS, Strasbourg, France.

${ }^{2}$ Now at U.S.-Israel Bi-national Science Foundation, Jerusalem, Israel.

Copyright 2011 by the American Geophysical Union. 0278-7407/11/2010TC002767
}

Mountains (BFM), which constitute the central part of these elevated shoulders, are not part of the original rift structure. They developed much later, requiring an explanation for their late uplift, and their rather limited extent along the graben flanks. Other unresolved issues regarding the URG include the debate on how much uplift was involved in the well documented Miocene erosion inside the graben [e.g., Roll, 1979]. Some other observations from the URG have been hardly discussed, including the origin of the long and deep linear sedimentary basin, which extends between Baden-Baden and Heidelberg. Also, along parts of both the eastern and western boundary fault systems, the main boundary fault is thought to consist of two master faults [Illies, 1977], rather than a conventional single, en echelon boundary fault system. This unusual characteristic has long been known, but otherwise received little attention.

[3] Toward the end of the last century, following the works of Sittler [1969, 1974] and Illies [1972, 1974, 1975, 1977, 1978], the geology of the URG was considered to be well known and the main effort shifted toward studying its deep structure mostly using seismic methods [e.g., Brun and Wenzel, 1991; Prodehl et al., 1995]. However, in recent years a renewed interest in the graben is evident, gaining 


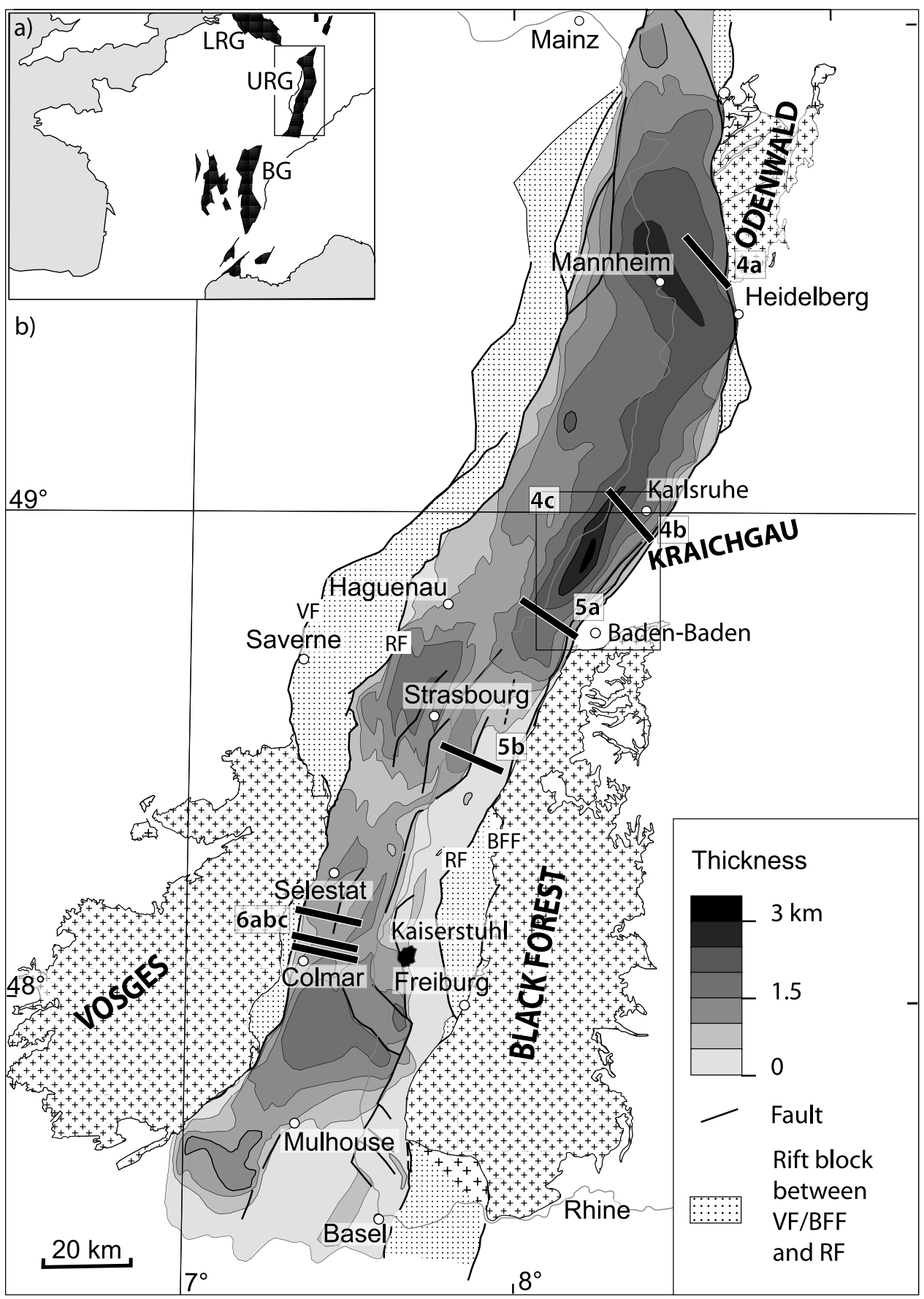

Figure 1. Map showing the main features of the Upper Rhine Graben. Sediment thickness is following Doebl and Olbrecht [1974] and Edel et al. [2007]. Also shown are the locations of seismic sections shown in Figures 4, 5, and 6. LRG, Lower Rhine Graben; BG, Bresse Graben; RF, Rhine Fault (east and west); BFF, Black Forest Fault; VF, Vosges Fault.

momentum by the recent release of most of the more modern seismic data acquired by oil companies in both its French and German parts. Although the renewed interest in the URG added a great deal of information, and new attempts were made to explain some of the observations from the graben, most of the unresolved issues are still open. In particular, there is still no satisfactory model, which is consistent with the various first-order observa- tions from the URG and accounts for its Early Miocene to Recent evolution.

[4] This paper discusses several of these well known observations that need to be part of, and consistent with, any model that attempts to account for the present structure of the URG. It then presents a very simple model that was previously proposed for the deep northern basin of the URG, to account for the other main features of the graben. Much of the data on which this work is based was described 


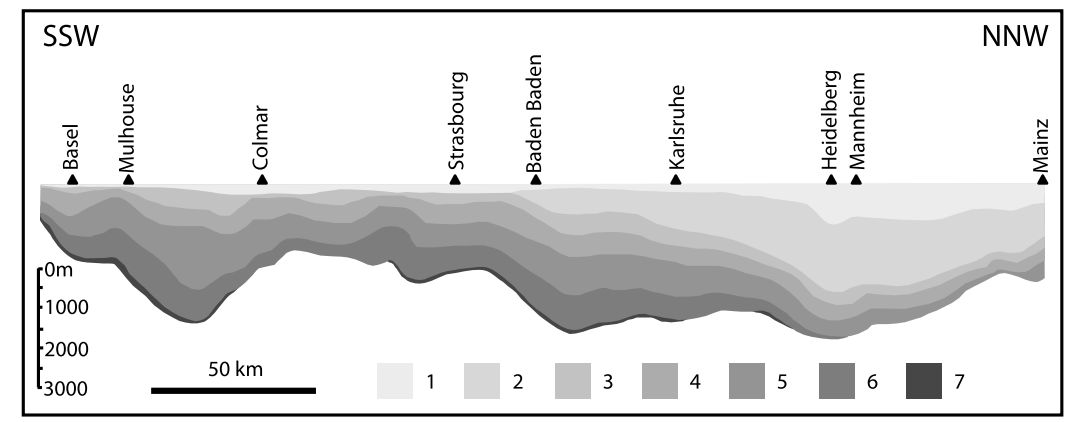

Figure 2. Simplified N-S geologic cross section of the URG [after Illies, 1974] (with permission; http:// www.schweizerbart.de/). Numbers are defined as follows: 1, Upper Pliocene-Pleistocene; 2, BurdigalianAquitanian; 3, Niederroeden beds; 4, Grey beds; 5, Pechelbronn beds; 6, Lymnaea maris; 7, Lutetium.

previously in a series of papers that discussed various parts of the graben [Rotstein and Schaming, 2004, 2008; Rotstein et al., 2005a, 2005b, 2005c], while the present work is a synthesis of these results into a unified, regional tectonic model. Thus, these previous papers show a great deal more seismic data that is directly relevant to the present work, while here we present only a few examples.

\section{Geological Setting}

[5] The URG is a dominant geological and geomorphologic structure that has an approximately NNE-SSW trend and extends for some $300 \mathrm{~km}$, from near Basel in the south, to near Mainz in the north (Figure 1). Extension and subsidence in the graben started during late Eocene, first mostly in the southern part in response to NNE trending Alpine compression [e.g., Illies, 1977; Villemin and Bergerat, 1987; Dèzes et al., 2004]. The main rifting phase ended in mid-Rupelian [Sissingh, 1998, 2003; Schumacher, 2002], but localized extension and subsidence continued into the Miocene, mostly in the northern part [Schumacher, 2002] (Figure 2). The internal structure of the URG was partly controlled by structures inherited from the Variscan orogeny and the subsequent Permo-Carboniferous wrench tectonics that formed several NE to ENE trending grabens, which crosscut it [Boigk and Schöneich, 1970; Ziegler et al., 2004; Edel et al., 2007]. Traditionally, the graben has been divided into southern, central and northern geomorphologic segments, trending $\mathrm{N} 15^{\circ} \mathrm{E}, \mathrm{N} 30^{\circ} \mathrm{E}$, and $\mathrm{N} 15^{\circ} \mathrm{W}$, respectively [Illies, 1977; Schumacher, 2002]. However, more recently, Rotstein et al. [2005a, 2006] argued that kinematically, the graben is divided only into a $\mathrm{N} 15^{\circ} \mathrm{W}$ trending northern segment and a combined central and southern segment with the main faults trending $\mathrm{N} 15^{\circ} \mathrm{E}$. Also recently, attempts were made to use rift units, which are the classical building blocks of continental rifts [Rosendahl, 1987], to describe the URG [Derer, 2003; Derer et al., 2005; Rotstein et al., 2006]. These use both the arc shape of some of the boundary faults, as well as the observation that the URG is asymmetrical in cross section and the asymmetry shifts sides along the graben as shown by Brun and Wenzel [1991].

[6] URG basement rocks are exposed on the flanks of the graben, mostly in the Black Forest and the Vosges Mountains but also in the Odenwald. They include a variety of intrusive, metamorphic and Cambrian to Visean sedimentary and volcanic rocks of the Variscan Internides
[Weidenbach and Vollrath, 1954; Fluck et al., 1987; Piqué et al., 1994]. Superimposed on this basement complex occur, in deep troughs, thick Permo-Carboniferous sediments containing rhyolites that appear in both the VM and BFM, as well as on the graben flanks farther north. The deeply truncated Variscan basement and Permo-Carboniferous series are unconformably covered by Mesozoic platform sediments. Tertiary synrift sediments, consisting mostly of marls, with some shales and sandstones, rest unconformably on the Mesozoic sediments. In the lower part of the Tertiary section, particularly in the southern URG, thick evaporites were deposited and occasionally developed into salt diapirs [e.g., Lutz and Cleintuar, 1999]. Thick Miocene-Pliocene shales and sands were deposited only in the northern URG while the southern parts of the graben were exposed to erosion at that time [Villemin et al., 1986; Dèzes et al., 2004] (Figure 2). During the Miocene (16 Ma [Wimmenauer, 2003]), a volcanic episode occurred in the southern URG, giving rise to the Kaiserstuhl volcano (Figure 1). Quaternary deposits, consisting of sands, gravels and shales, are found throughout the graben, but do not exceed a thickness of $300 \mathrm{~m}$ [Bartz, 1974].

\section{Stress History}

[7] The stress history of the URG since the Paleogene is related to major tectonic events in the Alpine and Pyrenean collision zones [Illies, 1978], and is characterized by a major change in the Early Miocene. The region experienced two main and well documented stress regimes although brief other regimes have also been proposed [Villemin and Bergerat, 1987; Schumacher, 2002]. The rifting phase (Figure 3, left) was associated with a vertical maximum compression $(\sigma 1)$ and an E-W [Villemin and Bergerat, 1987; Larroque and Laurent, 1988], ESE-WNW [Illies, 1977; Schumacher, 2002], or ENE-WSW [Behrmann et al., 2003 ] oriented horizontal minimum compression $(\sigma 3)$. The most significant change in the URG stress regime was the early Miocene shift of $\sigma 1$ from vertical to a horizontal position with a NW-SE trend, while $\sigma 3$ remained horizontal but rotated accordingly [Bergerat, 1987; Larroque et al., 1987; Villemin and Bergerat, 1987; Schumacher, 2002] (Figure 3, right). Under this new stress regime, which persisted to the present [Ahorner, 1975; Bonjer et al., 1984; Larroque et al., 1987; Müller et al., 1992; Bonjer, 1997; Plenefisch and Bonjer, 1997], the evolution of the URG was 


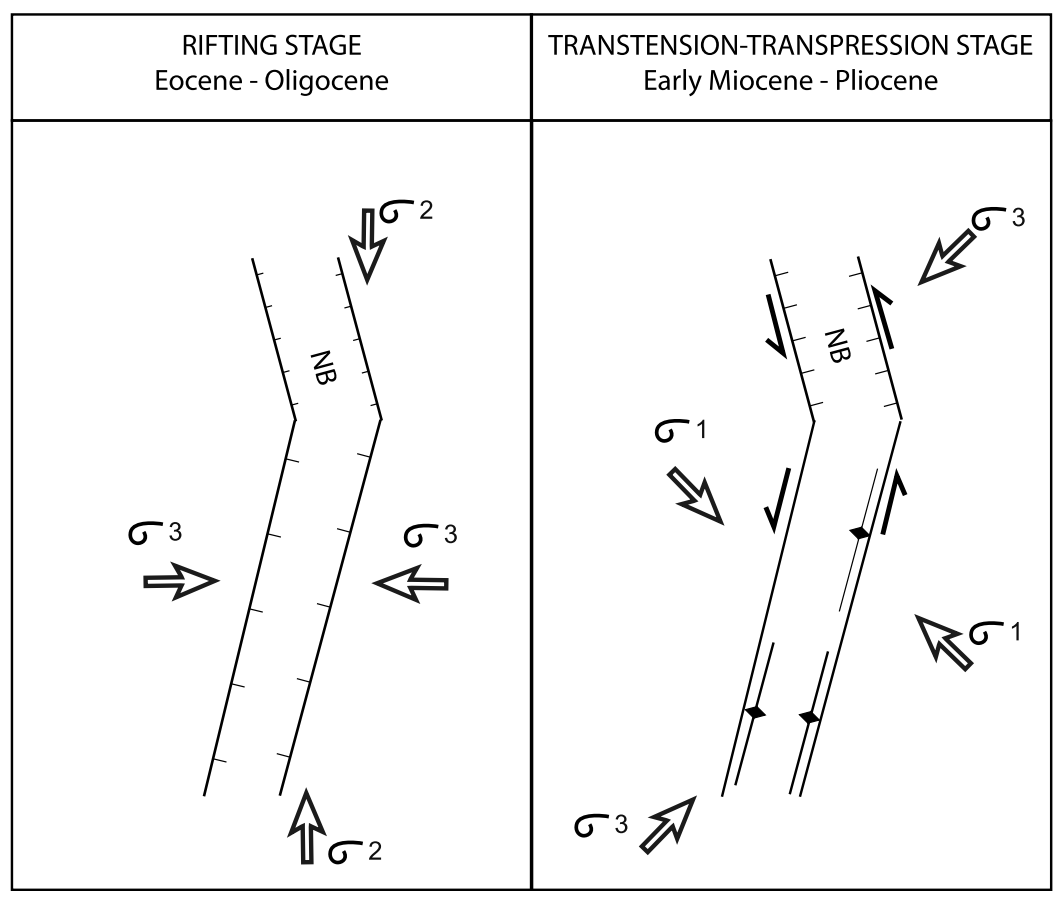

Figure 3. Schematic presentation of the two main phases in the stress history of the URG. (left) In the rifting stage $\sigma 1$ is vertical and $\sigma 3$ is oriented approximately E-W. (right) Starting in the early Miocene, $\sigma 1$ became horizontal in a NW-SE direction and $\sigma 3$ remained horizontal but rotated to a NE-SW direction, resulting in N-S directed transform motion in the URG. NB, Northern Basin.

dominated by a strike-slip movements, thus characterizing it as a continental transform with a sinistral, N-S trending motion [e.g., Illies, 1978; Schumacher, 2002]. This important change is generally attributed to the Early Miocene [Laubscher, 1992, 2003; Schumacher, 2002; Ziegler and Dèzes, 2007], although several other ages have also been proposed [Illies, 1977; Giamboni et al., 2004].

\section{Rift Structure}

[8] The thickness of rift sediments in the URG displays the internal structure of the graben (Figures 1 and 2) [Doebl and Olbrecht, 1974; Doebl and Teichmüller, 1979]. The Heidelberg-Mannheim Basin, called also the Northern Basin (NB), recently described using seismic reflection and well data [Derer, 2003; Derer et al., 2005], is presently the deepest basin inside the URG with up to over $3200 \mathrm{~m}$ of rift sediments. The NB sediments are mostly of Miocene and Pliocene age (Figure 2), indicating that it mainly developed after the main phase of extension and basin formation in the rest of the URG subsided [e.g., Schumacher, 2002]. It is delimited by distinct normal faults [e.g., Derer, 2003; Rotstein et al., 2005a] but typical divergent, syntectonic sedimentation next to the main fault is not evident in this westward tilted graben segment (Figure 4a) [Derer et al., 2005]. Farther south, a linear and narrow basin extends along the eastern margin of the rift for about $80 \mathrm{~km}$, and is approximately as deep as the NB (Figure 1). It was named by Schumacher [2002] the "Strasbourg Basin" and is named here the Heidelberg-Baden-Baden Basin. The sediments in this deep basin consist mainly of pre-Miocene rift sediments, and are therefore mostly older than the NB sediments. Also, the Heidelberg-Baden-Baden Basin is characterized by a deep syncline along its entire length (Figures $4 \mathrm{~b}$ and $4 \mathrm{c}$ ) [Breyer and Dohr, 1967; Breyer, 1974a; Rotstein et al., 2005a]. A distinct boundary fault is evident along the eastern flank of the syncline, but the depocenter is not adjacent to this fault as is typical for divergent, synsedimentation in tilted block morphology. Instead, the depocenter is located further west in the center of the syncline, across which the thickness of the sediments is rather constant. The different age of the sediments as well as their different internal structures suggest that the evolution of the NB and the Heidelberg-Baden-Baden basins differs substantially.

[9] The Southern URG is not as deep, and includes a series of fault controlled basins, the deepest of which is the $1600 \mathrm{~m}$ deep Mulhouse Salt Basin, north of the city of Mulhouse. Miocene and Pliocene sediments are missing in the central and southern URG, and a widespread erosional unconformity is apparent all the way from the Jura Mountains to the NB, with overlying Pliocene-Pleistocene sediments (Figure 2) [Roll, 1979; Lutz and Cleintuar, 1999; Ziegler and Dèzes, 2007; Wirsing et al., 2007]. Presently, although the erosional phase was clearly documented in numerous studies, the size of the associated uplift inside the graben is not well controlled. Estimates as high as 1000 $1500 \mathrm{~m}$ were proposed [Sittler, 1985; Lutz and Cleintuar, 1999], but these are based on indirect evidence, rather than on seismic reflection sections. The best estimate from the axis of the graben is based on seismic data from the southern edge the NB where Roll [1979] documented an erosion of several hundred meters.

[10] The URG is dominated by a series of large normal faults, as expected in an extensional environment. However, 

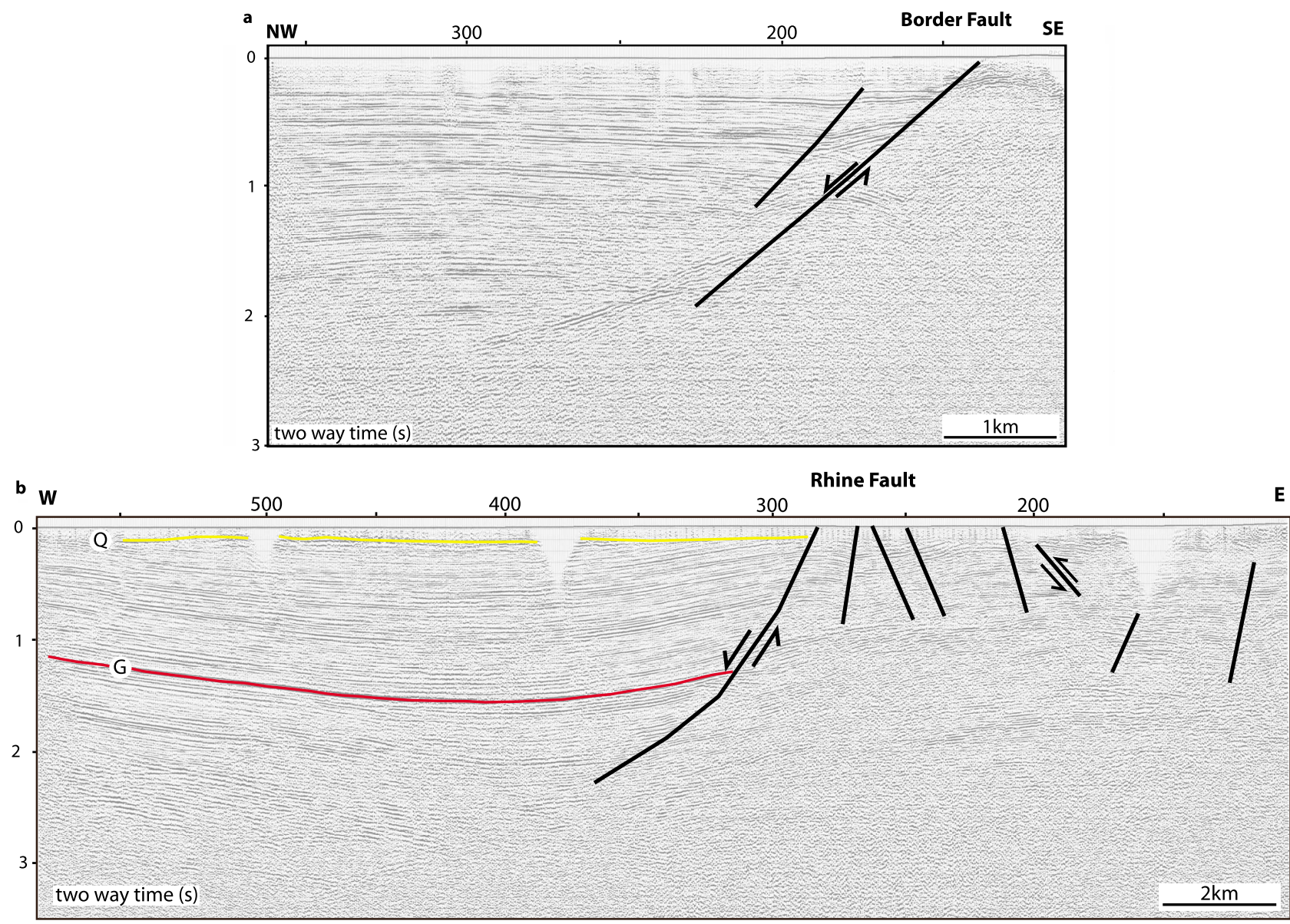

C

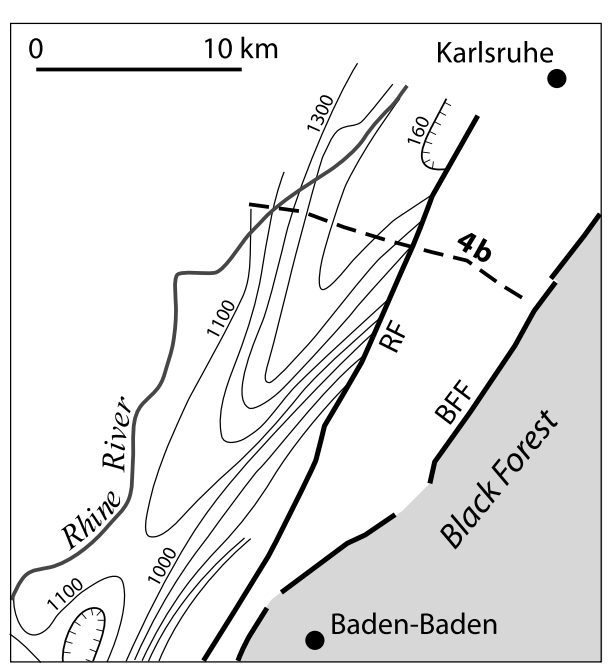

Figure 4. (a) Seismic reflection section across the eastern boundary fault in the NB, showing simple basin geometry, with horizontal sediments (modified from Rotstein et al. [2005a]). For location see Figure 1. (b) Seismic reflection section across the linear syncline that extends between Baden-Baden and Heidelberg. G, Melleta Fish seismic marker of Oligocene age; Q, Plio-Pleistocene erosional unconformity [after Rotstein et al., 2005a]. For location see Figures 1 and 4c). (c) Two-way travel time map to the Melleta Fish seismic marker, of part of the elongated syncline between Baden-Baden and Heidelberg, and location of the seismic line shown in Figure 4b (modified from Rotstein et al. [2005a]).

numerous studies have shown that synclines characterize not only the eastern boundary between Baden-Baden and Heidelberg, but most of the URG boundary with both the VM and BFM. In a series of ten cross sections from the south- ernmost part of the BFM to north of Baden-Baden, Breyer [1974b] showed that synclines next to the main boundary faults characterize much the boundary of the URG with the BFM. The configuration of these synclines is clearly imaged 
a
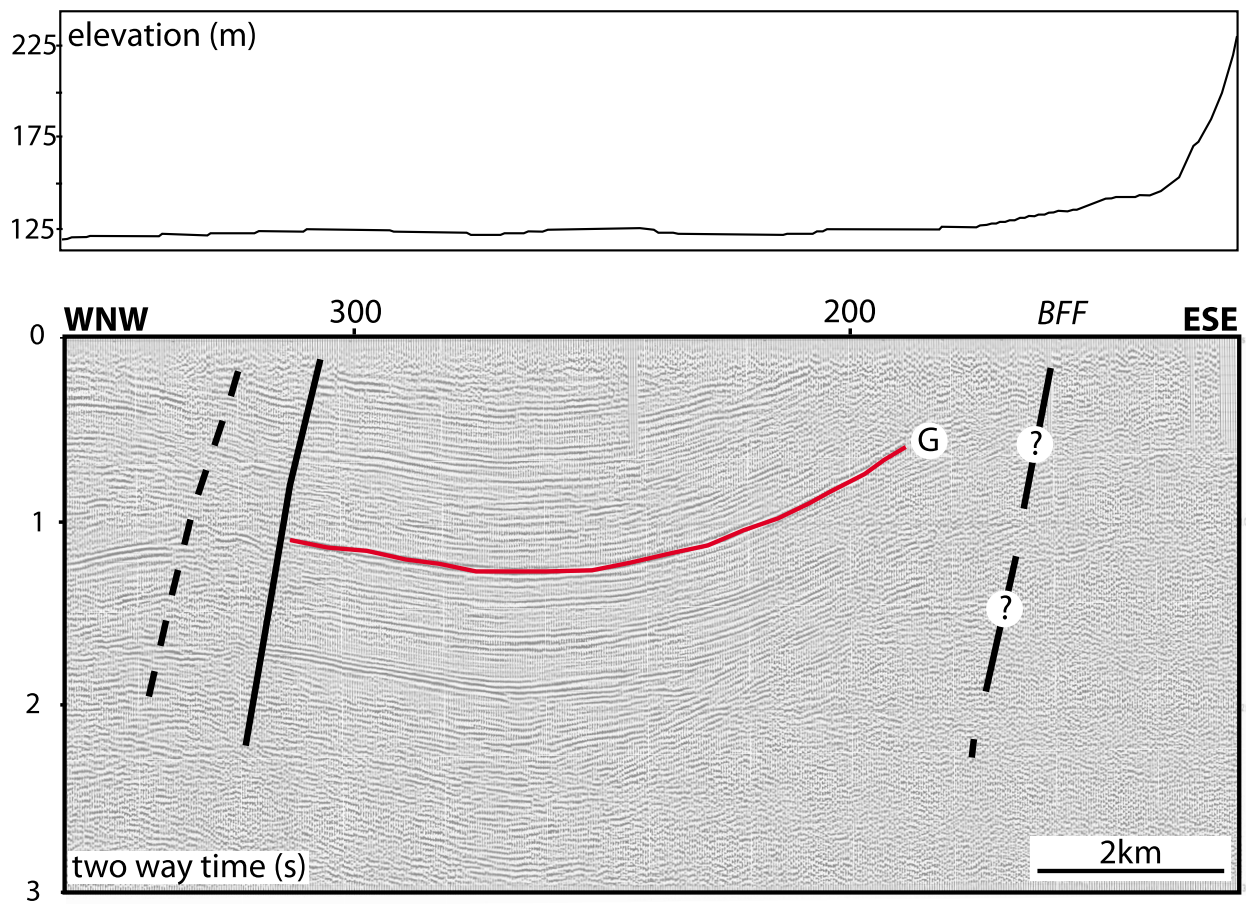

b
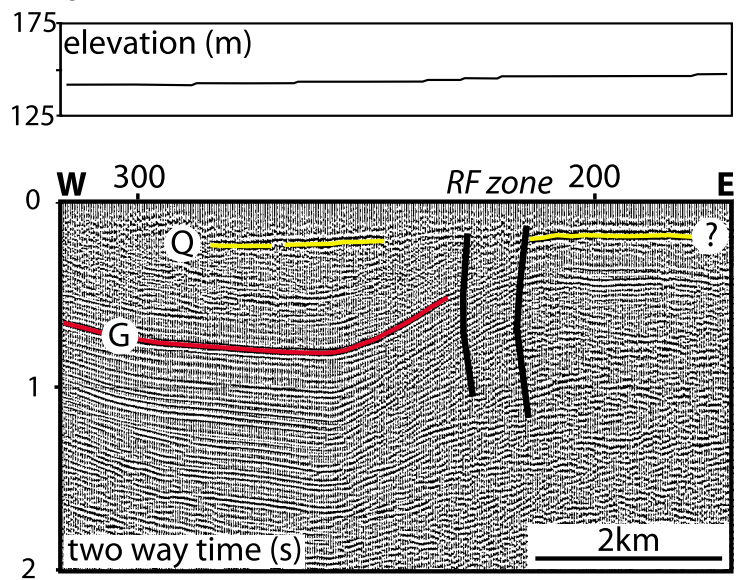

Figure 5. Two typical seismic sections from the eastern side of the URG next to the BFM. (a) Section crossing the Black Forest Fault (BFF) [after Rotstein et al., 2005a]. (b) Section crossing the Rhine Fault $(\mathrm{RF})$, further inside the graben showing compression. Note that along the southern BFM seismic data is scarce. For locations see Figure 1. For marker identification see Figure 4b.

by seismic lines [Erlinghagen and Dohr, 1974; Rotstein et al., 2005a], and in detailed cross sections [Breyer and Dohr, 1967]. They appear to be open, asymmetric synclines with the steeper slope immediately next to the eastern Rhine Fault (Figure 5), although some of the other normal faults along the boundary are also associated with similar synclines [Wirth, 1962]. A generally similar structure is observed adjacent to the western Rhine Fault zone along the boundary with the VM (Figure 6). The sediments that are involved in these folds include according to Rotstein et al. [2005a] and Rotstein and Schaming [2008] late Oligocene synrift series, suggesting that their deformation may be contemporaneous with the early Miocene change in the regional stress regime. On the western side of the graben, where mostly monoclines were previously observed, these were attributed to forced folding above synrift normal faults [Maurin, 1995; Maurin and Nivière, 2000; Le Carlier de Veslud et al., 2005; Ford et al., 2007]. However, all along the eastern side, as well as on parts of the western side of the graben, it is apparent that post rifting, Oligocene-early Miocene sediments with constant lateral thickness were affected by obviously younger folding. Also, in the eastern side these are mostly full synclines, rather than monoclines (Figure 5), which are not consistent with the forced folding 

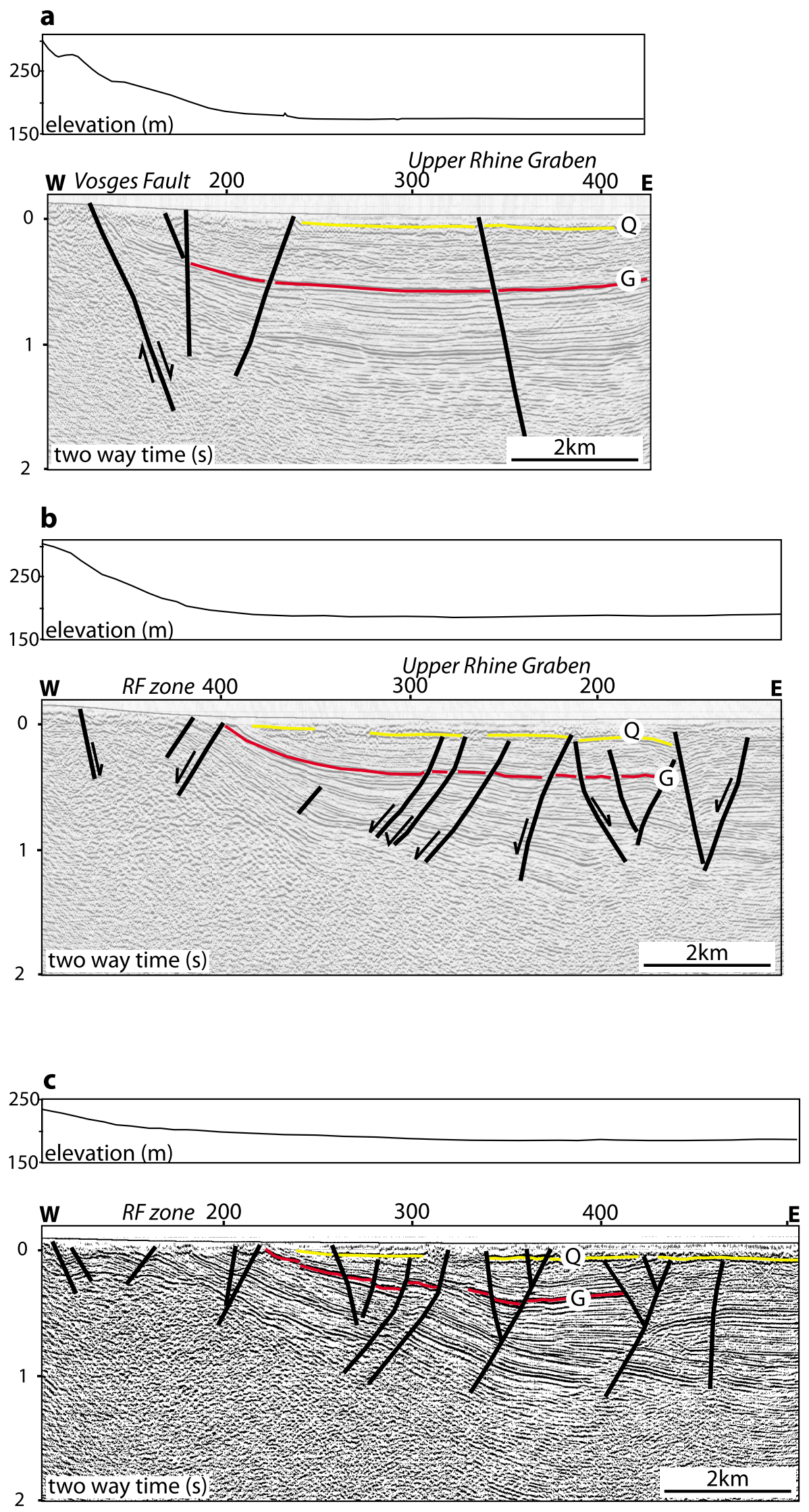

Figure 6 
hypothesis. The same conclusion was also reached by Laubscher [2001] who noted that downfolding led to the common assumption that it is related to rollover and drag faults, but attempts to model them as such have failed.

\section{Rift Shoulders Morphology}

[11] Rift shoulders are uplifted in response to the flexural isostatic adjustment of the lithosphere due to extension with a deep necking level [van Wees and Cloetingh, 1996]. With time rift shoulders loose their topographic prominence due to erosion and to the cooling of the lithosphere. The flanks of the URG are quite unusual in this respect. The NB, in which the alluvial plain is at an elevation of about $100 \mathrm{~m}$, is the deepest basin in the URG, and also where most of the Miocene to Recent extension occurred. Its shoulders peak at 400-700 m, only slightly above the regional elevation away from the graben. In contrast, the southern URG, where synrift sedimentation ended during the late Oligocene-early Miocene [Schumacher, 2002], is flanked by the prominent VM and BFM. These mountains peak at 1400-1500 m, while the URG basin in between is at an elevation of 130$230 \mathrm{~m}$. In an E-W section the southern URG has typical rift morphology, with steep slopes facing the rift, and a gradual drop in elevation away from it [see, e.g., Hinsken et al., 2007]. However, quantitative modeling suggested that the original rift shoulder uplifts associated with the Eocene rifting, were mostly eroded, and that the present VM and BFM are the result of a second, younger tectonic phase [Villemin et al., 1986]. This scenario is supported by the recent results of thermochronological studies that indicate rapid late-stage cooling from the late Miocene onward, resulting from increased erosion due to uplift [Timar-Geng et al., 2006]. Presently, it is commonly accepted that the VM and BFM were uplifted during the early Miocene, most probably in Burdigalian [e.g., Ziegler et al., 2002; Dèzes et al., 2004; Ziegler and Dèzes, 2007]. Pliocene [Illies, 1977] and younger [Duringer, 2001] ages were also proposed, but are not compatible with the southward shedding of the Serravallian-early Tortonian Jura Nagelfluh and its equivalents from the VM and BFM into the area of the Jura Mountains [Ziegler and Fraefel, 2009].

[12] Several additional observations from the flanks of the URG might be of help in trying to account for their rather unusual uplift history. First, we note that in both mountain ranges the highest parts are close to their southern end, and that their heights drop gradually toward the north. Second, the northern edge of the BFM appears to coincide with the southern edge of the prominent Heidelberg-Baden-Baden elongated syncline inside the graben, possibly suggesting that there is an inherent relation between them.

\section{Boundary Faults}

[13] The URG is characterized by prominent eastern and western boundary fault systems (Figure 1). As shown by
Rosendahl [1987], the border faults of continental rifts, which separate the sediment filled graben and the uplifted graben shoulders, consist of a series of normal faults that in a map view typically display an arcuate shape. These arcuate faults are usually laterally continuous along the rift and are also often the external faults in a series of semiparallel faults that extend into the graben. Usually, the inner faults in these systems do not form continuous, or en echelon systems that extend for a large distance along the rift. The URG appears to be somewhat different in this regard, having along large parts of its western and eastern boundaries, two sets of dominant fault zones. These are the Vosges and (western) Rhine Fault zones along much of the eastern boundary of the VM, and the Black Forest and (eastern) Rhine Fault zones along the boundary with the BFM (Figure 1) [Sittler, 1969; Brun and Wenzel, 1991; Schumacher, 2002]. The role of the arc shaped Vosges and Black Forest Fault systems as classical rift boundary faults appears to be evident, marking the initial breakaway of the graben. In contrast, the role of the western and eastern Rhine Faults is not as clear. As expected in a rift environment, each of these Rhine Fault systems has a large normal component [Brun and Wenzel, 1991; Rotstein et al., 2005a; Rotstein and Schaming, 2008], but otherwise they are quite different from the Vosges and Black Forest faults. They are semilinear and appear to be laterally continuous along the graben, with an en echelon arrangement (Figure 1). Thus, they are quite similar to faults that have both a normal and a strike-slip component as, for example, faults in the Dead Sea Rift.

[14] We note that although the two faults arrangement characterizes large parts of the URG, in other parts of the graben only a single, linear boundary Fault System is apparent. The areas where the two faults (Vosges and Rhine Faults on the west and Black Forest and Rhine Faults on the east) diverge are those in which the Vosges and Black Forest fault zones have an arcuate shape in a map view. These include mostly parts of the VM and BFM, and the Saverne block west of Strasbourg, where the Rhine fault delimits the deeper parts of the basin rather than forming part of the boundary zone itself. In areas where the Vosges and Black Forest Fault zones are approximately linear, only a single boundary fault is observed: for example, east and northeast of Strasbourg, as well as segments of the eastern and southern boundaries of the VM (Figure 1).

\section{Discussion}

[15] Although the URG has some of the characteristics of a typical intracontinental rift, it is also associated with a series of features indicating that it underwent a complex tectonic history. Several of the features that characterize the URG appear to be temporally related, all occurring in the early Miocene: (1) change of the URG from an extensional to a strike-slip feature, commonly referred to as a continental transform; (2) renewed uplift of the shoulders of the southern URG; (3) rapid subsidence of the NB; and

Figure 6. $(\mathrm{a}-\mathrm{c})$ Three typical seismic sections from the boundary between the URG and the VM. Above the sections are the topographic profiles along the lines. Note the monocline and the uplift and erosion of the sediments at the boundary fault. Also, what may appear as divergent sedimentation away from the boundary fault in Figure $6 \mathrm{~b}$ is actually the result of numerous small faults. The premarker Q sediments are laterally constant in thickness. RF, Rhine Fault (western). Figures $6 \mathrm{~b}$ and $6 \mathrm{c}$ are from Rotstein and Schaming [2008]. For locations see Figure 1. For marker identification see Figure 4b. 
(4) onset of the erosional and nondepositional phase in the central and southern parts of the URG.

[16] Several attempts have been made to correlate pairs of these observations, but there was never an attempt to correlate all of them together. Nevertheless, since all four events appear to be both spatially and temporally related, it is likely that they can be explained by a single mechanism that triggered the rest of them. If so, this mechanism can also, possibly, explain some of the unusual features of the URG, such as its complex boundary fault systems, and the Heidelberg-Baden-Baden syncline.

[17] The observation that drew most attention in recent years was the renewed uplift of the VM and BFM, which was accompanied by uplift of the intervening graben, causing widespread erosion [Illies, 1977; Roll, 1979; Sissingh, 1998; Schumacher, 2002]. This uplift of the southern URG and its shoulders was attributed to an Alpine forebulge [Sinclair et al., 1991; Laubscher, 1992], or to a mantle diapir centered at the Kaiserstuhl volcano [Illies, 1972; Villemin et al., 1986; Ziegler, 1992]. However, Gutscher [1995] noted that the dome shape of this proposed uplift is not consistent with the surface and Moho topographies of the adjacent regions, and explained it as an Alpine related lithospheric flexural bulge. Alternatively, Ziegler [1994], Ziegler et al. [2002], Dèzes et al. [2004] and most recently Ziegler and Dèzes [2007] proposed that the Vosges-Black Forest Arch developed by lithospheric folding in response to the buildup of collision related compressional stresses [see also Bourgeois et al., 2007]. This concept is compatible with the Moho topography that describes a gentle SW-NE trending anticline extending from the northern parts of the Massif Central across the URG to the Bohemian Massif. This debate, indicate that the uplift mechanism of the URG shoulders is not yet resolved.

[18] Large-scale Miocene uplift of the VM and BFM implies that the original shoulders of the URG were low standing toward the end of the Oligocene. This was also shown by the quantitative analysis of Villemin et al. [1986], and by sedimentological studies [Duringer, 2001]. Renewed lithospheric, or any other regional uplift, have affected the sediments inside the URG as well, and not only its eroded shoulders. Moreover, being at the center of this uplift, the sediments in the rift may have been elevated more than its shoulders. This scenario can be avoided by large-scale and contemporaneous renewed normal faulting on the boundary faults, which would lower the rift sediments with respect to the shoulders, and create the present morphology. Such a scenario, which is consistent with the extension that is inherent in a regional uplift, has never been documented. Its absence was explained by Ziegler and Dèzes [2007] by the noncylindrical nature of the lithospheric folding and by the resulting continued transtensional movements along the URG border faults. Questions regarding the regional uplift hypothesis arise also from the longitudinal cross section (Figure 2), which shows that south of the fault controlled NB the contacts between the sedimentary packages are regionally flat, and fail to indicate doming.

[19] The well documented, widespread erosion in the URG south of the NB is the main direct evidence that is used to support a regional uplift. The largest documented erosion in the center of the graben is on the southern slope of the NB, and is in the order of several hundred meters
[Schad, 1964; Roll, 1979]. However, since that much erosion is not documented elsewhere along the axis of the graben, this intense erosion appears to be quite local and may require an alternative explanation. For example, considering the large amount of the Neogene subsidence in the $\mathrm{NB}$, the erosion can possibly be also explained by a classical rift margin uplift of the subsiding NB. We note that where a large uplift did occur, such as in the northern [Schad, 1964], eastern [Rotstein et al., 2005a] and western [Rotstein and Schaming, 2008] margins of the central and southern $\mathrm{URG}$, its associated erosion is easily identifiable in the seismic sections. Deep inside the central and southern URG the seismic data show evidence for erosion, but it is clearly much less prominent than along the margins (Figures 5 and 6). Thus, although it is rather obvious the sediments throughout the entire southern URG were uplifted in what may be termed a "regional uplift," there is no evidence that this uplift is related to a regional lithospheric folding that included also the rift's margins.

[20] Another pair of early Miocene events that were proposed to be tectonically related is the onset of transform motion in the URG and the extension, subsidence and rapid sedimentation in the NB. The NNW-SSE trending NB deviated from the $\mathrm{N}-\mathrm{S}$ trend of the transform motion, resulting in releasing bend geometry and in transtensionally driven subsidence of over $2000 \mathrm{~m}$ since early Miocene [Illies, 1978; Schumacher, 2002]. The same investigators also noted that in some other parts of the URG, easterly deviations from the $\mathrm{N}-\mathrm{S}$ trend of the transform motion occurred, and must have been associated with local transpression. However, they were short of using transtension and transpression to explain the other early Miocene tectonic events in the URG. We suggest that this Miocene strike-slip motion played a much more important role in the tectonics of the region than previously realized. Not only can it explain the origin of the NB, but it can also explain the renewed uplift of the VM and BFM, and account for much of its present-day structure and morphology. At the same time that the NB was subsiding due to transtension, other large parts of the URG along its active faulted boundaries must have been uplifted by transpression. This is implied kinematically by the NNE-SSW trend of the boundary faults in the central and southern parts of the graben (Figure 3).

[21] Transpression is a well known phenomenon. Where it is associated with restraining bends in continental transforms, it results in particularly prominent features such as the San Gabriel Mountains along the San Andreas Fault in California [e.g., Rust, 1998], or the Lebanon and AntiLebanon Mountains in Lebanon and Syria [e.g., Butler et al., 1998], where the Dead Sea Transform assumes a more easterly trend. Although the transform nature of the URG since the early Miocene is well established, little is known about the magnitude of related horizontal offsets, which presumably were small and in no way comparable to that of the San Andreas or even to that of the Dead Sea Fault. However, even without large lateral displacements when the pole of rotation is close, implying that the relative motion is reduced laterally, the interaction may be "extremely efficient at uplifting rocks quickly" [Fossen and Tikoff, 1998]. For this to take place, a bend in the fault is not needed, and the fault may be linear, provided that the direction $\sigma 1$ implies a 
significant component of compression across it, as is the case in the Miocene URG. Thus, even though the Miocene URG is definitely not comparable to the large present-day transforms, there is no a priori reason to exclude transpression from playing a significant role in its development. The expected extent and amplitude of the transpressionally derived structures in the URG may be inferred from a comparison with the NB. The $15^{\circ}$ westerly deviation of the $\mathrm{NB}$ from the N-S trend of the transform motion resulted in Miocene subsidence of the NB by more than $2000 \mathrm{~m}$. Similarly, the approximately $15^{\circ}$ easterly deviation from $\mathrm{N}-\mathrm{S}$, of most of the boundary faults in the rest of the graben, must have resulted in transpressional structures with amplitudes that are as large as that of the NB. Moreover, the regional stress regime reflects Alpine events, and the central, and in particular the southern part of the URG, are closer to the Alps than the NB. Thus, these areas might have experienced larger stresses than in the NB, leading to even more prominent structures.

[22] A number of observations from the boundaries between the URG and both the BFM and VM suggest that transpression, which is required kinematically in the early Miocene stress environment, indeed occurred. For example, a striking example of compression is from the southern part of the BFM, where Laubscher [2001] found that the boundary with the URG is characterized by thrusting. He interpreted it as indicating transpression. He also described a similar sedimentary folding next to the boundary fault, as we describe here, and noted that it is the result of downbuckling. Similar folds associated with the rift boundary fault in this area were also shown by Gürler et al. [1987]. Additional evidence for thrusting along the boundary of the BFM is from a quarry near Baden-Baden [Illies and Greiner, 1978] and well data [Wirth, 1950; Hauber, 1993]. Two older seismic sections from the boundary between the URG and the BFM show a large uplift and erosion next to the boundary faults [Erlinghagen and Dohr, 1974], as did the ten geological sections from along the entire western boundary of the BFM [Breyer, 1974b]. More recently, a large number of newly released seismic reflection lines from the URG, enabled a more systematic and detailed examination of the boundaries of the URG [Rotstein et al., 2005a; Rotstein and Schaming, 2008]. They showed that along the boundary of the URG with both the VM and BFM, the sediments adjacent to the main faults are uplifted with respect to the sediments in the center of the graben. These uplifts, which are clearly larger than elsewhere inside the URG, are evidenced by the erosion of the sediments that, at places, is larger than $1000-1500 \mathrm{~m}$, supporting the central role of the transpression in the tectonics of the URG (Figures 5 and 6). Rotstein and Schaming [2008] also showed, as expected in a transpressional environment, that the amount of transpressionally driven uplift along the boundary changes over short distances, with changes in the direction of the boundary fault. For example, south of Colmar where the trend of RF is known to be N-S, in the direction of the transform motion, the original listric shape of the RF is preserved, with a large throw and with little other deformation. In contrast, north of Colmar where the boundary trends $\mathrm{N} 15^{\circ} \mathrm{E}$, considerable deformation is apparent along the boundary, and the Tertiary rift sediments are uplifted by at least $1500 \mathrm{~m}$, and eroded (Figure 6). These studies, which also showed that the URG boundaries north of the BFM and VM are not characterized by similar uplift and erosion, concluded that the boundaries of the URG with the two mountain ranges were associated with marked transpression. They noted that apart from the uplift and erosion, also the down-buckling of the sediments along the boundaries characterize the transpression in the URG, as noted previously by Laubscher [2001] in the southeast corner of the graben. These open synclines and monoclines not only extend along large parts of the boundaries, they also reach large amplitudes. Therefore, they are significant tectonic features that although known for a long time, were not recognized as such.

[23] Rotstein et al. [2005a] documented an early Miocene transpression along the boundary between the URG and the BFM, but were short of suggesting that it caused the early Miocene uplift of the BFM. On the other side of the URG, Rotstein et al. [2005b] speculated that the VM were uplifted in the early Miocene by transpression, but had only limited direct evidence for it. More recently, Rotstein and Schaming [2008] used the newly released seismic data from the eastern boundary of the VM to show similar transpressional features that were previously known only from the BFM. In particular, they showed direct evidence that the sediments next to the boundary with the VM were elevated and eroded, serving as a key to understanding the entire system. They interpreted it as an indication that the uplift of the VM was driven by transpression. The similar observations of uplift, erosion and folding in the sediments next to the boundaries with both the VM and BFM set the stage for suggesting that not only the VM, but rather both shoulders of the southern URG were elevated by transpression. Since the uplift of each of the two flanks was due to similar but separate processes on its boundary faults, the two were not necessarily part of a regional uplift. Therefore, and although the sediments between the BFM and VM were clearly uplifted and eroded uplift in the center of the URG that was as large as that of the margins, is also not likely. This result is also consistent with the observation that while the VM and BFM were uplifted, the rift segment between them remained in a "quasi neutral position during this time" [Illies, 1975]. Limited compression must have been transmitted into the rift from both sides, resulting in uplift and widespread erosion of preuplift/pre-early Miocene sediments. However, the lack of post early Miocene sediments between the VM and BFM is likely to be mostly explained by nondeposition. Schematic characteristics of the BFM and the URG part next to them are shown in Figure 7. The URG sediments are down-buckled by several hundred meters, and the BFM and the sediments immediately next to it are uplifted at the boundary. This uplift and associated erosion prevented the accumulation of early Miocene and younger sediments in the accommodation space caused by the down buckling of the sediments. The entire BFM may also be somewhat folded [Ortlam, 1974]. Across the rift, at the VM boundary, this picture is more consistent with the northern VM that experienced less transpression, while next to the higher part of the VM in the south, the uplifted sediments form a monocline, rather than a syncline (Figure 6) [Rotstein and Schaming, 2008]. Unfortunately, seismic data from the URG boundary with the high BFM is scarce. 


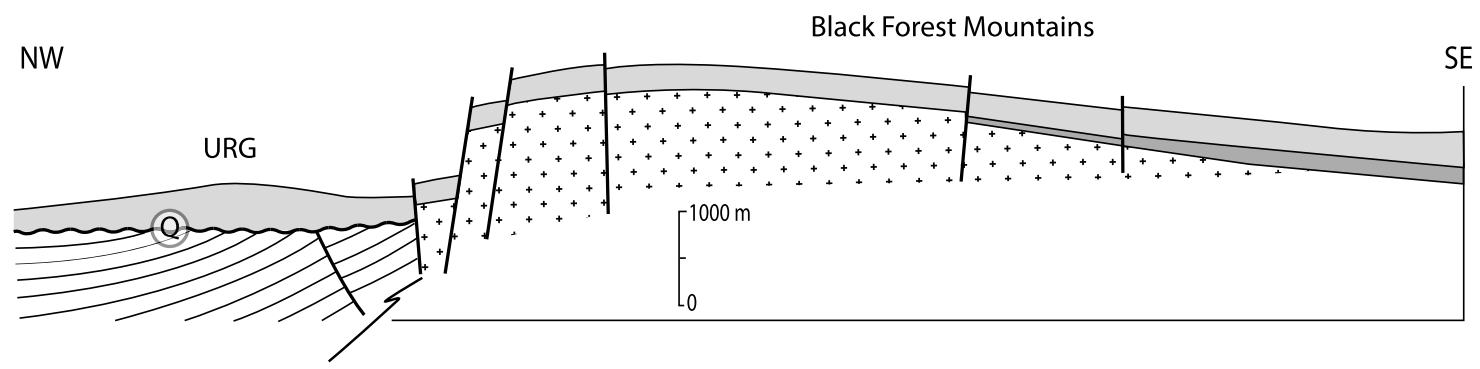

Figure 7. Schematic cross section across the BFM and the eastern part of the southern URG (BFM part after Ortlam [1974] (with permission; http://www.schweizerbart.de/)). Q is the Plio-Pleistocene unconformity. The boundary of the URG with the VM is the mirror image of this image.

[24] We note that since the seismic method is not effective on the rift shoulders, it is not possible to directly document transpressional characteristics there. Nevertheless, we suggest that although the VM and BFM are more rigid and heavy than the extruded rift sediments, they were uplifted as well. Should they not have been uplifted, and considering the dips of the boundary faults, it means that the rift sediments were thrusted over the rift shoulders. Very large thicknesses of such overthrusted sediments would have left evidence on the rift shoulders. Also, the temporal coincidence of a regional lithospheric uplift, which is the commonly used alternative model for the shoulder uplift, with an unrelated uplift and extrusion of the sediments next to the boundaries of the southern URG is, of course possible, but seems unlikely. We note that in some recent papers the important role of early Miocene transpression in the URG has been recognized. In particular, Ziegler and Dèzes [2007] and Ziegler and Fraefel [2009] acknowledge that transpression was an important element in the development of the URG. They suggest that the early Miocene uplift of the Vosges-Black Forest Arch was in response not only to lithospheric folding, but also to accompanying transpressional deformation and uplift of the southern parts of the URG.

[25] Down-buckling of the sediments due to transpression can also account for the deep Heidelberg-Baden-Baden sedimentary basin. This basin fills the gap between the BFM, where transpression resulted in rift shoulder uplift, and the NB that at the same time was characterized by transtensionally driven subsidence. The trend of this part of the boundary is not much different than further south [Rotstein et al., 2006]. Thus, a deep syncline, which affects the mostly pre-Miocene rift sediments, can hardly be explained by anything else but transpression. However, it is not evident why the response to transpression in this boundary segment did not involve shoulder uplift as it did along the BFM. Possibly, the observation that north of the BFM transpression resulted only in folding reflects the decaying stress away from the Alpine system. Northward decay of the stress can also be used to explain why the strongest transpression, manifested by the highest peaks of the VM and BFM, is near their southernmost end and their height declines northward. Such a scenario is also consistent with the laterally decaying stresses required for efficient uplift of the BFM, according to the modeling (type A transpression in the work by Fossen and Tikoff [1998]).
[26] As recently discussed for the boundary faults of the VM [Rotstein and Schaming, 2008], we suggest that the arcuate Black Forest Fault System probably represents the original breakaway faults of the URG from the BFM. However, when transform motion became dominant, these arc shaped faults were deactivated while, the Rhine Faults, which were existing, inner and more linear normal faults, became more active. Thus, while both the Vosges and Black forest Fault Systems appear to be almost purely normal faults, the Rhine Fault Systems on both sides of the URG are likely to have also strike-slip components. In contrast, where the original boundary was approximately linear, for example in the NB, this arrangement had no mechanical advantage, and only a single boundary fault is present.

[27] The presently available evidence for late Tertiary compression and uplift of the URG shoulders appears to be compelling, and transpression and transtension are thought to characterize the URG even at present [Buchmann and Connolly, 2007]. Nevertheless, for many years Miocene transpression was not identified as an important process in the evolution of the URG. Transpressional deformation in the URG is mostly limited to the immediate vicinity of the main boundary faults, and is less apparent deeper inside the graben, or on its shoulders. Also, as noted by Laubscher [2001], the down-buckling that characterize transpression in the URG does not appear to be similar to the more common "squeezing out" of the graben content that characterize inversion tectonics. There also might be a fundamental difference between the transpression in the URG, and a classical transpression in a restraining bend. In the latter, the energy and deformation is concentrated in the bend area only. As a result, strong deformation is expected there, which may also extend laterally away from the fault to a larger distance (Figure 8). In contrast, in the URG the Miocene transpression must have been distributed over the entire length of linear boundaries, and the amount of energy involved in the compression per unit length of the fault was smaller, limiting the deformation to the fault area only.

[28] Finally, the part of the URG boundaries, which may be the most interesting tectonically appears to be the SW-NE trending southern boundary of the VM. This segment trended normal to the NW-SE directed principal stress component controlling the transform motions. Therefore, in this area the transpression must have been the largest, possibly accounting for the particularly large width of the southern part of the VM. Unfortunately, there are no seismic lines that crossed this part of the boundary of the graben, 


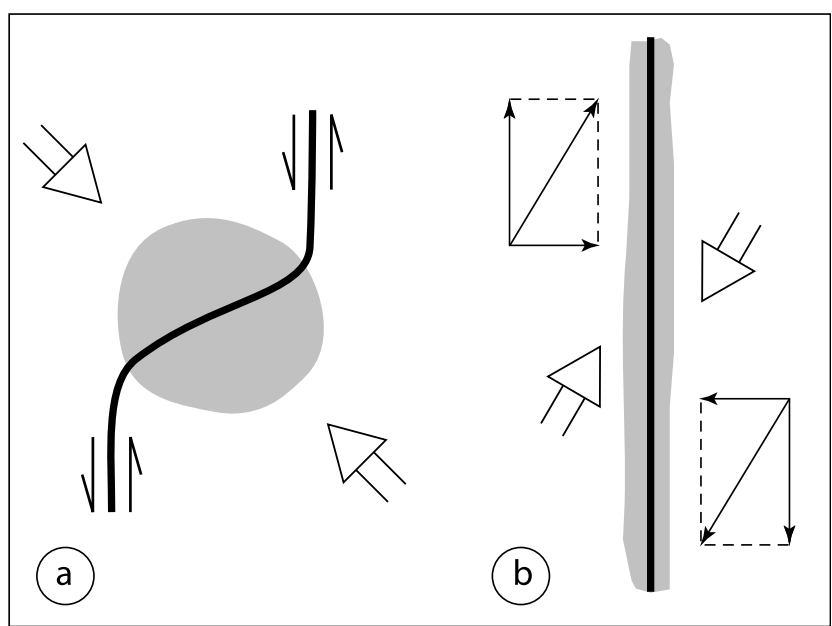

Figure 8. Schematic transpression of restraining bend situation (a) and linear fault with the strike-slip motion at an angle (b). Grey area denotes compression/transpression. In a linear situation the transpression usually characterizes a larger segment and thus can be more contained in the vicinity of the fault.

and little is known about its configuration [Rotstein et al., 2005b].

\section{Conclusions}

[29] Upon the early Miocene buildup of the NNW directed stress field in the area of the URG, the southern, NNE striking part of the URG was transpressionally reactivated while its northern NNW striking part was transtensionally reactivated. This resulted in the transtensional subsidence of the deep NB and the transpressional uplift of the VM and the BFM. Transpression in the southern URG was most intense in the vicinity of the main boundary faults, but its effects also spilled into the central part of the graben but were much less intense. However, this compression away from the boundaries may have been sufficient to cause the observed uplift and widespread erosion of the preuplift sediments, followed by nondeposition. Presently, since lithospheric folding is hard to prove or disprove, it is impossible to rule out that observed structure of the southern URG is the combined result of early Miocene transpression and lithospheric folding. However, the observation that by far the largest uplifts were along the boundaries with the VM and BFM suggest that a regional uplift alone cannot account for the observed structure. Strong effects of the transpression not only did not extend deep inside the rift, but also did not extend deep inside the rift shoulders, which were passively elevated by the transpression across the boundary faults. Since the regional stress was caused by Alpine events, its magnitude can be expected to diminish away from the Alps, resulting in lesser deformation in the central and northern URG. Finally, we note that whereas the more apparent transpression is usually associated with a restraining bend, the URG fault system is more linear, and transpression there had very different characteristics that made it more difficult to identify. Unlike simple inversion in rifts that attracted a great deal of attention, partially because it is easily identified in seismic sections, transpression in mature rifts have not been studied much. Yet, statistically, such intermediate stress rotations are likely to be as abundant as rotations of the stress into a full inversion. Their newly acquired strike slip component is often hard to identify in seismic data, but understanding these processes can have considerable economic implications. The URG, about which so much is known, appears to be an excellent place to study grabens that underwent rotations of the regional stress, which resulted in transpression on their main faults.

[30] Acknowledgments. The authors wish to thank P. Ziegler for very constructive comments that improved the manuscript a great deal. We also thank Vermillion Energy, Wirtschaftsverband Erdöl, and Erdgasgewinnung e.V. for permission to use the seismic reflection data. Finally, we thank J.-B. Edel for his figure that we used as the basis for our Figure 1

\section{References}

Ahorner, L. (1975), Present day stress field and seismotectonic block movements along major fault zones in central Europe, Tectonophysics, 29, 233-249, doi:10.1016/0040-1951(75)90148-1.

Bartz, J. (1974), Die Mächtigkeit des Quartärs im Oberrheingraben, in Approaches to Taphrogenesis, Inter-Union Commiss. Geodyn., Sci. Rep., vol. 8, edited by J. H. Illies and K. Fuchs, pp. 78-87, Schweizerbart, Stuttgart, Germany.

Behrmann, J. H., O. Hermann, M. Horstmann, D. C. Tanner, and G. Bertrand (2003), Anatomy and kinematics of oblique continental rifting revealed: A three-dimensional case study of the southeast Upper Rhine Graben (Germany), AAPG Bull., 87, 1105-1121, doi:10.1306/02180300153.

Bergerat, F. (1987), Stress fields in the European platform at the time of Africa-Eurasia collision, Tectonics, 6, 99-132, doi:10.1029/ TC006i002p00099.

Boigk, H., and H. Schöneich (1970), Tiefenlage der Permbasis im nördlichen Teil des Oberrheingrabens, in Graben Problems: Proceedings of an International Rift Symposium Held in Karlsruhe 1968, edited by J. H. Illies and S. Mueller, pp. 45-55, Schweizerbart, Stuttgart, Germany.

Bonjer, K.-P. (1997), Seismicity pattern and style of seismic faulting at the eastern border fault of the southern Rhine Graben, in Stress and Stress Release in the Lithosphere-Structure and Dynamic Processes in the Rifts of Western Europe, edited by K. Fuchs et al., Tectonophysics, $275,41-69$.

Bonjer, K.-P., C. Gelbke, R. Gilg, D. Rouland, D. Mayer-Rosa, and B. Massinon (1984), Seismicity and dynamics of the Upper Rhinegraben, J. Geophys., 55, 1-12.

Bourgeois, O., M. Ford, M. Diraison, C. Le Carlier de Veslud, M. Gerbault, R. Pik, N. Ruby, and S. Bonnet (2007), Separation of rifting and lithospheric folding signatures in the NW-Alpine foreland, Int. J. Earth Sci., 96, 1003-1031, doi:10.1007/s00531-007-0202-2.

Breyer, F. (1974a), Die Entstehungsgeschichte des Südteils des Rheinsgraben Nach Reflexionsseismischen Messungen, Geologischen Kartierungen und Tiefbohrungen, Geol. Jahrb., Reihe A, 20.

Breyer, F. (1974b), Structure and development of the southern part of the Rhine Graben according to geological and geophysical observations, in Approaches to Taphrogenesis, Inter-Union Commiss. Geodyn., Sci. Rep., vol. 8, edited by J. H. Illies and K. Fuchs, pp. 145-154, Schweizerbart, Stuttgart, Germany.

Breyer, F., and G. Dohr (1967), Bemerkungen zur Stratigraphie und Tectonik des Rheintalgrabens zwischen Karlsruhe und Offenburg, Abh. Geol. Landesamtes Baden-Wuerttemb., 6, 42-43.

Brun, J. P., and F. Wenzel (1991), Crustal scale structure of the southern Rhinegraben from ECORS-DEKORP seismic reflection data, Geology, 19, 758-762, doi:10.1130/0091-7613(1991)019<0758: CSSOTS $>2.3$. $\mathrm{CO} ; 2$.

Buchmann, J. T., and P. T. Connolly (2007), Contemporary kinematics of the Upper Rhine Graben: A 3D finite element approach, Global Planet. Change, 58, 287-309, doi:10.1016/j.gloplacha.2007.02.012.

Butler, R. W. H., S. Spencer, and H. M. Griffiths (1998), The structural response to evolving plate kinematics during transpression: Evolution of the Lebanese restraining bend of the Dead Sea Transform, in Continental Transpressional and Transtensional Tectonics, edited by R. E. Holdsworth, R. A. Strachan, and J. F. Dewey, Geol. Soc. Spec. Publ., $135,81-106$. 
Derer, C. E. (2003), Tectono-sedimentary evolution of the northern Upper Rhine Graben (Germany), with special regard to the early syn-rift stage, Ph.D. thesis, 99 pp., Univ. of Bonn, Bonn, Germany. (Available at http:// hss.ulb.uni-bonn.de/2003/0263/0263.htm.)

Derer, C. E., M. E. Schumacher, and A. Schäfer (2005), The northern Upper Rhine Graben: Basin geometry and early syn-rift tectono-sedimentary evolution, Int. J. Earth Sci., 94, 640-656, doi:10.1007/s00531-005-0515-y.

Dèzes, P., S. Schmid, and P. A. Ziegler (2004), Evolution of the Cenozoic Rift System: Interaction of the Alpine and Pyrenean orogens with their foreland lithosphere, Tectonophysics, 389, 1-33, doi:10.1016/j. tecto.2004.06.011

Doebl, F., and W. Olbrecht (1974), An isobath map of the Tertiary base in the Rhinegraben, in Approaches to Taphrogenesis, Inter-Union Commiss. Geodyn., Sci. Rep., vol. 8, edited by J. H. Illies and K. Fuchs, pp. 71-72, Schweizerbart, Stuttgart, Germany.

Doebl, F., and M. Teichmüller (1979), Zur Geology und heutigen Geothermik im mittleren Oberrhein-Graben, Fortschr. Geol. Rheinl. Westfalen, 27, 1-17.

Duringer, P. (2001), Fossé Rhénan. Excursion Guide for the EUCORURGENT Workshop, 52 pp., Mt. St. Odile, France.

Edel, J.-B., K. Schulmann, and Y. Rotstein (2007), The Variscan inheritance of the Upper Rhine Graben: Evidence for reactivations in the Lias, the late Eocene-Oligocene and in recent times, Int. J. Earth Sci., 96, 305-325, doi:10.1007/s00531-006-0092-8.

Erlinghagen, L., and G. Dohr (1974), Beiträge der Reflexionsseismik zur Frage der Schwarzwaldrandstörung, in Approaches to Taphrogenesis, Inter-Union Commiss. Geodyn., Sci. Rep., vol. 8, edited by J. H. Illies and K. Fuchs, pp. 138-144, Schweizerbart, Stuttgart, Germany.

Fluck, P., J.-B. Edel, C. Gagny, R. Montigny, A. Piqué, J. L. Schneider, and H. Whitechurch (1987), Géologie du socle vosgien, Doc. BRGM, 146, 1-97.

Ford, M., C. Le Carlier de Veslud, and O. Bourgeois (2007), Kinematic and geometric analysis of fault-related folds in rift setting: The Dannemarie basin, Upper Rhine Graben, France, J. Struct. Geol., 29, 1811-1830, doi:10.1016/j.jsg.2007.08.001

Fossen, H., and B. Tikoff (1998), Extended models of transpression and transtension, and application to tectonic settings, in Continental Transpressional and Transtensional Tectonics, edited by R. E. Holdsworth, R. A. Strachan, and J. F. Dewey, Geol. Soc. Spec. Publ., 135, 15-33.

Giamboni, M., A. Wetzel, B. Nivière, and M. Schumacher (2004), PlioPleistocene folding in the southern Rhinegraben recorded by the evolution of the drainage network (Sundgau area; northwestern Switzerland and France), Eclogae Geol. Helv., 97, 17-31, doi:10.1007/s00015-0041112-4.

Gürler, B., L. Hauber and M. Schwander (1987), Die Geologie der Umgebung von Basel, Beitr. Geol. Karte Schweiz, 160.

Gutscher, M.-A. (1995), Crustal structure and dynamics in the Rhine Graben and Alpine foreland, Geophys. J. Int., 122, 617-636, doi:10.1111/j.1365-246X.1995.tb07016.X.

Hauber, L. (1993), Der südliche Rheingraben und seine geothermische Situation, Bull. Ver. Schweiz Pet.-Geol. Ing., 60(137), 53-69.

Hinsken, S., K. Ustaszewski, and A. Wetzel (2007), Graben width controlling syn-rift sedimentation: The Paleogene southern Upper Rhine Graben as an example, Int. J. Earth Sci., 96, 979-1002, doi:10.1007/s00531-0060162-y.

Hüttner, R. (1991), Bau und Entwicklung des Oberrheingrabens, Ein Überblick mit historischer Ruckschau, Geol. Jahrb., 48, 17-42.

Illies, J. H. (1972), The Rhine Graben rift system-Plate tectonics and transform faulting, Geophys. Surv., 1, 27-60, doi:10.1007/BF01449550.

Illies, J. H. (1974), Intra-Plattentektonik in Mitteleuropa und der Rheingraben, Oberrheinische Geol. Abh., 23, 1-24.

Illies, J. H. (1975), Recent and paleo-intraplate tectonics in stable Europe and the Rhinegraben rift system, Tectonophysics, 29, 251-264, doi:10.1016/0040-1951(75)90149-3.

Illies, J. H. (1977), Ancient and recent rifting in the Rhinegraben, Geol Mijnbouw, 56, 329-350.

Illies, J. H. (1978), Two stages of Rhinegraben rifting, in Tectonics and Geophysics of Continental Rifts, edited by I. B. Ramberg and E. R. Neumann, pp. 63-71, D. Reidel, Dordrecht, Netherlands.

Illies, J. H., and G. Greiner (1978), Rhinegraben and the Alpine system, Geol. Soc. Am. Bull., 89, 770-782, doi:10.1130/0016-7606(1978) $89<770:$ RATAS $>2.0 . \mathrm{CO} ; 2$

Larroque, J.-M., and P. Laurent (1988), Evolution of the stress field pattern in the south of the Rhine Graben from the Eocene to present, Tectonophysics, 148, 41-58, doi:10.1016/0040-1951(88)90159-X.

Larroque, J.-M., A. Etcheccopar, and H. Philip (1987), Evidence for the permutation of stresses $\sigma 1$ and $\sigma 2$ in the Alpine foreland: The example of the Rhine Graben, Tectonophysics, 144, 315-322, doi:10.1016/ 0040-1951(87)90299-X.
Laubscher, H. (1992), Jura kinematics and the Molasse Basin, Eclogae Geol. Helv., 67, 121-133.

Laubscher, H. (2001), Plate interactions at the southern end of the Rhine Graben, Tectonophysics, 343, 1-19, doi:10.1016/S0040-1951(01) 00193-7.

Laubscher, H. (2003), The Miocene dislocations in the northern foreland of the Alps: Oblique subduction and its consequences (Basel area, Switzerland-Germany), Jahresber. Mitt. Oberrheinischen Geol. Ver., $85,423-439$.

Le Carlier de Veslud, C., O. Bourgeois, M. Diraison, and M. Ford (2005), 3D stratigraphic and structural synthesis of the Dannemarie basin (Upper Rhine Graben), Bull. Soc. Geol. Fr., 176, 433-442, doi:10.2113/ 176.5 .433

Lutz, M., and M. Cleintuar (1999), Geological results of a hydrocarbon exploration campaign in the southern Upper Rhine Graben (Alsace Centrale, France), Bull. Appl. Geol., 4, 3-80.

Maurin, J.-C. (1995), Drapage et décollement des séries Jurassiques sur la faille de détachement majeure du rift rhénan sud: Des dépôts syn-rifts oligocènes, C. R. Acad. Sci., Ser. Ila Sci. Terre Planetes, 321(11), 1025-1032.

Maurin, J.-C., and B. Nivière (2000), Extensional forced folding and décollement of the pre-rift series along the Rhine Graben and their influence on the geometry of the syn-rift sequences, in Forced Folds and Fractures, edited by J. W. Cosgrove and M. Ameen, Geol. Soc. Spec. Publ.. 169, 73-86

Müller, B., M. L. Zoback, K. Fuchs, L. Mastin, S. Gregersen, N. Pavoni, O. Stephansson, and C. Ljunggren (1992), Regional patterns of tectonic stress in Europe, J. Geophys. Res., 97(B8), 11,783-11,803, doi:10.1029/91JB01096.

Ortlam, D. (1974), Die Tektonik des nördlichen Schwarzwaldes und ihr Beziehung zum Oberrheingraben, in Approaches to Taphrogenesis, Inter-Union Commiss. Geodyn., Sci. Rep., vol. 8, edited by J. H. Illies and K. Fuchs, pp. 160-166, Schweizerbart, Stuttgart, Germany.

Pflug, R. (1982), Bau und Entwicklung des Oberheingrabens, 145 pp., Wiss. Buchgesellschaft, Darmstadt, Germany.

Piqué, A., P. Fluck, J. L. Schneider, and H. Whitechurch (1994), The Vosges Massif, in Pre-Mesozoic Geology in France, edited by J. D. Keppie, pp. 416-425, Springer, Berlin

Plenefisch, T., and K.-P. Bonjer (1997), The stress field in the Rhine Graben area inferred from earthquake focal mechanisms and estimation of frictional parameters, Tectonophysics, 275, 71-97, doi:10.1016 S0040-1951(97)00016-4

Prodehl, C., S. Mueller, and V. Haak (1995), The European Cenozoic rift system, Dev. Geotecton., 25, 133-212, doi:10.1016/S0419-0254(06) 80012-1.

Roll, A. (1979), Versuch einer Volumenbilanz des Oberrheintalgrabens und seiner Schultern, Geol. Jahrb., Reihe A, 52, 1-82.

Rosendahl, B. R. (1987), Architecture of continental rifts with special reference to East Africa, Annu. Rev. Earth Planet. Sci., 15, 445-503, doi:10.1146/annurev.ea.15.050187.002305

Rotstein, Y., and M. Schaming (2004), Seismic reflection evidence for thick-skin tectonics in the northern Jura, Terra Nova, 16, 250-256, doi:10.1111/j.1365-3121.2004.00560.x

Rotstein, Y., and M. Schaming (2008), Tectonic implications of faulting styles along a rift margin: The boundary between the Rhine Graben and the Vosges Mountains, Tectonics, 27, TC2001, doi:10.1029/ 2007 TC002149.

Rotstein, Y., J. H. Behrmann, M. Lutz, G. Wirsing, and A. Luz (2005a), Tectonic implications of transpression and transtension: The Upper Rhine Graben, Tectonics, 24, TC6001, doi:10.1029/2005TC001797.

Rotstein, Y., M. Schaming, and S. Rousse (2005b), Tertiary tectonics of the Dannemarie basin, Upper Rhine Graben, and regional implications, Int. J. Earth Sci., 94, 669-679, doi:10.1007/s00531-005-0473-4.

Rotstein, Y., M. Schaming, and S. Rousse (2005c), Structure and Tertiary tectonic history of the Mulhouse High, Upper Rhine Graben: Block faulting modified by changes in the Alpine stress regime, Tectonics, 24, TC1012, doi:10.1029/2004TC001654.

Rotstein, Y., J.-B. Edel, G. Gabriel, D. Boulanger, M. Schaming, and M. Munschy (2006), Bouguer gravity of the Upper Rhine Graben: Interplay between lateral changes in the rift structure and in basement composition, Tectonophysics, 425, 55-70, doi:10.1016/j.tecto.2006.07.002.

Rust, D. (1998), Contractual and extensional structure in the transpressive "Big Bend" of the San Andreas Fault, southern California, in Continental Transpressional and Transtensional Tectonics, edited by R. E. Holdsworth, R. A. Strachan, and J. F. Dewey, Geol. Soc. Spec. Publ., 135, 119-126.

Schad, A. (1964), Feingliederung des Miozäns und Deutung der nacholigozänen Bewegungen im Mittleren Rheingraben-Eine Auswertung erdölgeologischer Arbeiten, Abh. Geol. Landesamtes Baden-Wuerttemb., $5,1-56$. 
Schumacher, M. E. (2002), Upper Rhine Graben: Role of preexisting structure during rift evolution, Tectonics, 21(1), 1006, doi:10.1029/ 2001TC900022.

Sinclair, H. D., B. J. Coakley, P. A. Allen, and A. B. Watts (1991), Simulation of foreland basin stratigraphy using diffusion model of mountain belt uplift and erosion: An example from the central Alps, Switzerland, Tectonics, 10, 599-620, doi:10.1029/90TC02507.

Sissingh, W. (1998), Comparative Tertiary stratigraphy of the Rhine Graben, Bresse Graben and Molasse Basin: Correlation of Alpine foreland events, Tectonophysics, 300, 249-284, doi:10.1016/S0040-1951(98) 00243-1.

Sissingh, W. (2003), Tertiary paleogeographic and tectonostratigraphic evolution of the Rhenish Triple Junction, Palaeogeogr. Palaeoclimatol. Palaeoecol., 196, 229-263.

Sittler, C. (1969), Le fossé Rhénan en Alsace: Aspect structural et histoire géologique, Rev. Geogr. Phys. Geol. Dyn., 11, 465-494.

Sittler, C. (1974), Le fossé Rhénan ou la plaine d'Alsace, in Géologie de la France, vol. 1, edited by J. Debelmas, pp. 78-104, Doin Editeurs, Paris

Sittler, C. (1985), Les hydrocarbures d'Alsace dans le contexte historique et géodynamique du fossé Rhénan, Bull. Cent. Rech. Explor.-Prod. ElfAquitaine, 9(2), 335-371.

Teichmüller, M., and R. Teichmüller (1979), Zur Geothermischen Geschichte des Oberrheingrabens. Zusammenfassung und Auswertung eines Symposiums, Fortschr. Geol. Rheinl. Westfalen, 27, 109-120.

Timar-Geng, Z., B. Fügenschuh, A. Wetzel, and H. Dressman (2006), Low temperature thermochronology of the flanks of the southern Upper Rhine Graben, Int. J. Earth Sci., 95, 685-702, doi:10.1007/s00531-005-0059-1.

van Wees, J. D., and S. Cloetingh (1996), 3D flexure and intraplate compression in the North Sea Basin, Tectonophysics, 266, 343-359, doi:10.1016/S0040-1951(96)00197-7.

Villemin, T., and F. Bergerat (1987), L'évolution structurale du fossé rhénan au cours du Cénozoïque: Un bilan de la déformation et des effets thermiques de l'extension, Bull. Soc. Geol. Fr., 8, 245-255.

Villemin, T., F. Alvarez, and J. Angelier (1986), The Rhinegraben: Extension, subsidence and shoulder uplift, Tectonophysics, 128, 47-59, doi:10.1016/0040-1951(86)90307-0

Weidenbach, F., and A. Vollrath (1954), Geologisches Übersichtskarte von Südwestdeutschland, scale 1:600,000, Geol. Landesamt, BadenWürttemberg, Germany

Wimmenauer, W. (2003), Geologische Karte von Baden-Württemberg, scale 1:25,000, in Erläuterungen zum Blatt Kaiserstuhl, 5th ed.
Landesamt für Geol., Rohstoffe und Bergbau, Freiburg im Breisgau, Germany.

Wirsing, G., A. Luz, W. Engesser, and A. Koch (2007), Hochauflösende Reflexionsseismik auf dem Rhein und dem Rheinseitenkanal Zwischen Mannheim und Rheinfelden, LGRB-Fachbericht, vol. 1/07, 60 pp., Freiburg, Germany.

Wirth, E. (1950), Die Erdölvorkommen von Bruchhal in Baden, Geol. Jahrb., 65, 655-706.

Wirth, E. (1962), Die Geologischen Ergebnisse der Erdölexploration in der Rheinebene zwischen Offenburg und Lahr, Erdoel Kohle Erdgas Petrochem., 159(9), 684-692.

Ziegler, P. A. (1992), European Cenozoic rift system, Tectonophysics, 208, 91-111, doi:10.1016/0040-1951(92)90338-7.

Ziegler, P. A. (1994), Cenozoic rift of western and central Europe: An overview, Geol. Mijnbouw, 73, 99-127.

Ziegler, P. A., and P. Dèzes (2007), Cenozoic uplift of Variscan Massifs in the Alpine foreland: Timing and controlling mechanisms, Global Planet. Change, 58, 237-269, doi:10.1016/j.gloplacha.2006.12.004.

Ziegler, P. A., and M. Fraefel (2009), Response of drainage systems to Neogene evolution of the Jura fold-thrust belt and Upper Rhine Graben, Swiss J. Geosci., 102, 57-75.

Ziegler, P. A., G. Bertotti, and S. Cloetingh (2002), Dynamic processes controlling foreland development: The role of mechanical (de)coupling of orogenic wedges and forelands, in Continental Collision and the Tectono-Sedimentary Evolution of Forelands, Stephan Mueller Spec. Publ., vol. 1, edited by G. Bertotti, K. Schulmann, and S. Cloetingh, pp. 29-91, Copernicus, Katlenburg-Lindau, Germany.

Ziegler, P. A., M. E. Schumacher, P. Dèzes, J.-D. van Wees, and S. Cloetingh (2004), Post-Variscan evolution of the lithosphere in the Rhine Graben area: Constraints from subsidence modeling, in Permo-Carboniferous Magmatism and Rifting in Europe, edited by M. Wilson et al., Geol. Soc. Spec. Publ., 223, 289-317.

Y. Rotstein, U.S.-Israel Bi-national Science Foundation, 9 Hamarpeh St., Jerusalem 91450, Israel. (yair@bsf.org.il)

M. Schaming, Institut de Physique du Globe de Strasbourg, UMR 7516 , Université de Strasbourg/EOST, CNRS, 5 Rue René Descartes, F-67084 Strasbourg, France. 